This study was sponsored by Hoechst AG. We thank A Roudani, Laboratoires CIRAB, Casabalanca, for the laboratory measurements; $P$ Herrmann and coworkers, Laboratoires Polymedic, Casablanca, for logistical support; G Gammel, Central Nervous Drug Research, Bensheim, Germany, for the statistical evaluation; $H$ Noack, Hoechst AG, for statistical appraisal; $M$ Uhl, Hoechst AG, for monitoring; and, especially, all the nursing staff for their dedication.

1 Rashed AH. The fast of Ramadan. No problems for the well: the sick should avoid fasting. BMF 1992;302:521-2.

2 Rashed AH. Clinical problems during fast of Ramadan. Lancet 1989;i:1396.

3 Sulimani RA, Famuyiwa FO, Laajam MA. Diabetes mellitus and fasting: the need for a critical appraisal. Diabetic Med 1988;5:589-91.

4 International Diabetes Federation. IDF Directory 1991. Brussels: IDF, 1991

5 Sulimani RA, Laajam M, Al-Attas O, Famuyiwa FO, Bashi S, Mekki MO et al. The effect of Ramadan fasting on diabetes control in type II diabetic patients. Nutrition Research 1991;11:261-4.

6 Chamakhi S, Ftouhi B, Ben Rhomdhane N, Ghorbal S, Ben Khalifa F. Influence du jeune de Ramadan sur l'equilibre glycemique chez les diabetiques. Proceedings of the 3rd meeting of the Mediterranean group for the study of diabetes, Nice, France, November 29-December 2, 1990. Medicographia 1991;13 (suppl 1):27-9.

7 Abu Jayyab A, Al-Nakhi A, Richens ER, Siboo R, Ai-Khafaji M, Behbehan
$K$. The effect of fasting on the metabolic control of non-insulin dependent diabetes. Medical Principles and Practice 1989:1:214-20.

8 Chandalia HB, Bhargaav A, Kataria V. Dietary pattern during Ramadan fasting and its effect on the metabolic control of diabetes. Practical Diabetes 1987;4:287-90.

9 Chea SH, Ch'Ng SL, Husain R, Duncan MT. Effects of fasting during Ramadan on urinary excretion in Malaysian Muslims. Br $\mathcal{f}$ Nutr 1990;63: 329-37.

10 El-Hazmi MAF, Al-Faleh FZ, Al-Mofleh IA. Effect of Ramadan fasting on the values of haematological and biochemical parameters. Saudi Medical foumal 1987;8:171-6.

11 Kruse-Jarres JD, Jarausch J, Lehmann P, Vogt BW, Rietz P. A new colorimetric method for the determination of fructosamine. Laboratoriums Medizin 1989;13:245.

12 Teupe B. Quantitative determination of glycated hemoglobin using affinity chromatography. Ohio: ISOLAB, 1987.

13 Armitage $P, B$ erry $G$. Statistical methods in medical research. Oxford: Blackwell, 1987.

14 Hochberg Y, Tamhane AC. Multiple comparison procedures. New York: Wiley, 987.

15 Schmahl FW, Metzler B. The health risks of occupational stress in Islamic industrial workers during the Ramadan fasting period. Pol $f$ Occup Med 1991;4:219-28.

16 Simmons D, Williams DRR, Powell MJ. The Coventry Diabetes Study: prevalence of diabetes and impaired glucose tolerance in Europeans and Asians. Qf Med 1991;81:1021-30.

17 Elhamy $R$, Yacout $T$, Ishak $K$. Guidelines to the fasting diabetic patient during Ramadan. Frankfurt: Hoechst AG, 1993.

(Accepted 29 April 1993)
Institut National de la Santé et de la Recherche Médicale, Unit 21, Hôpital Paul Brousse, 94807 Villejuif, France

B Balkau, research scientist

E Eschwège, director of

research

L Papoz, director of research

Institut National de la Santé et de la Recherche

Médicale, Unit 258,

Hôpital Broussais, 75674

Paris, France

J-L Richard, director of

research

$\mathrm{P}$ Ducimetière, director of research

Laboratoire de la Direction de l'Action Sociale, de

l'Enfance et de la Santé, Centre Médico-Social, 75013 Paris, France

J-R Claude, professor

$\mathrm{J}-\mathrm{M}$ Warnet, professor

Correspondence to: Dr Balkau.

BMF 1993;307:295-9

15

\title{
Risk factors for early death in non-insulin dependent diabetes and men with known glucose tolerance status
}

B Balkau, E Eschwège, L Papoz, J-L Richard, J-R Claude, J-M Warnet, P Ducimetière

\section{Abstract}

Objective-To identify risk factors for all cause mortality according to glucose tolerance status.

Design-Cohort study with an average 15.6 years' follow up.

Setting-Paris, France.

Subjects-7166 working men aged 44-55 in 1968-72 in the Paris prospective study cohort, with noninsulin dependent diabetes or known result of two hour $75 \mathrm{~g}$ oral glucose tolerance test.

Main outcome measures-Risk factors for death from all causes.

Results-128 men were known to be diabetic, 180 had diabetes diagnosed, and 697 had impaired glucose tolerance diagnosed. Compared with normoglycaemic men the relative risks of death in these groups were $2.0(95 \%$ confidence interval 1.4 to 3.0$)$, $2.7(2.0$ to 3.6$)$, and $1.6(1.3$ to 2.0$)$ respectively. Obesity, smoking, high blood pressure, and high non-esterified fatty acid concentration were risk factors for death in all subjects and were unaffected by glucose tolerance. The risks for fasting and two hour insulin concentrations and mean corpuscular volume were two times higher in known diabetic men than in men not known to be diabetic. Central obesity was significant only in men not known to be diabetic (1.6 (1.4 to 1.9$))$. In known diabetic men a two hour glucose concentration higher than 11.1 mmol/h carried a relative risk of death of $3.8(1.4$ to 9.4).

Conclusions-Diabetic men have similar risk factors for early mortality to other men but are at higher risk from hyperinsulinaemia, hyperglycaemia, and high mean corpuscular volume.

\section{Introduction}

Subjects with non-insulin dependent diabetes have a reduced life span, with an age specific mortality about twice that of the general population. ${ }^{1}$ This excess mortality has been attributed principally to ischaemic heart disease. ${ }^{1}$ Our analysis of the 44-55 year old men in the Paris prospective study cohort showed that diabetic subjects (known and newly diagnosed) had an increased risk of death from other causes as well. Compared with subjects who were normoglycaemic, the diabetic subjects had a relative risk of death from all causes of $2.31(95 \%$ confidence interval 1.81 to 2.93$)$ after 15 years of follow up, similar to that for coronary heart disease $2 \cdot 26(1 \cdot 25$ to $3 \cdot 79){ }^{2}$ These results parallel those from the Gothenburg study of middle aged men, which reported odds ratios of $3.5(2.5$ to 6.9$)$ for death and 4.1 $(2.5$ to 6.6$)$ for death from coronary heart disease in known diabetic subjects after seven years of follow up. ${ }^{3}$ We analysed risk factors associated with death in diabetic men.

\section{Subjects and methods}

At the beginning of 1967, 8297 male civil servants born between 1917 and 1928 were eligible to participate in the Paris prospective study of cardiovascular risk factors. The general aims and detailed methods of this study, as well as the characteristics of this population, have been described. ${ }^{45}$ Of the 8297 subjects, $96 \%$ were examined initially, and a further $3 \%$ were excluded from analysis because they were born outside France. At the first annual follow up examination 7038 of the men (aged 44-55 years) completed a two hour $75 \mathrm{~g}$ oral glucose tolerance test. A further 128 subjects were known to have diabetes and had been or were being treated with hypoglycaemic drugs; the ten men receiving insulin were not included. All subjects who were not known to be diabetic were classified, on the basis of their fasting and two hour glucose concentrations and the World Health Organisation 1985 criteria. ${ }^{6}$ Newly diagnosed diabetes was defined as fasting glucose $\geqslant 7.8 \mathrm{mmol} / 1$ or two hour glucose $\geqslant 11.1$ $\mathrm{mmol} / \mathrm{l}$, or both; impaired glucose tolerance as fasting glucose $<7.8 \mathrm{mmol} / \mathrm{l}$ and two hour glucose $7 \cdot 8-11 \cdot 1$ $\mathrm{mmol} / \mathrm{l}$; and normoglycaemia as fasting glucose $<7 \cdot 8$ $\mathrm{mmol} / \mathrm{l}$ and two hour glucose $<7.8 \mathrm{mmol} / \mathrm{l}$.

The men were asked about their smoking habits. Body mass index (weight/(height) $)^{2}\left(\mathrm{~kg} / \mathrm{m}^{2}\right)$ ), central obesity (ratio of iliac and thigh circumferences), ${ }^{7}$ and blood pressure (measured with the subject in a 


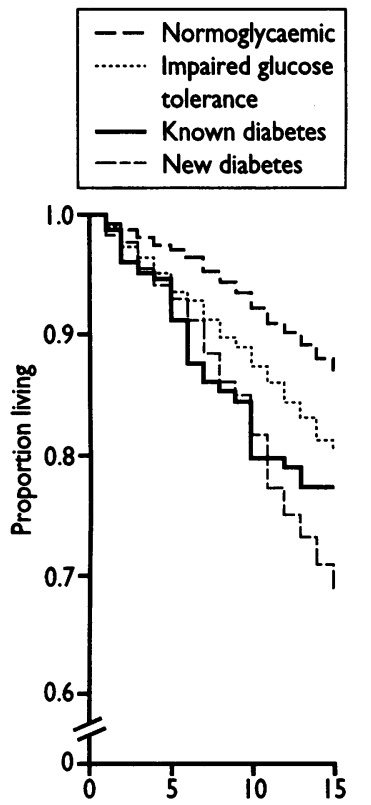

Follow up time (years)

Survival curves estimated from Cox model after adjustment for age according to glucose tolerance seated position and to the nearest $10 \mathrm{~mm} \mathrm{Hg}$ ) were also recorded. Blood samples were taken when fasting and two hours after the oral glucose tolerance test; samples were analysed for plasma cholesterol, ${ }^{8}$ triglycerides," glucose, ${ }^{10}$ non-esterified fatty acids, ${ }^{11}$ and insulin ${ }^{12}$ concentrations. Few data were missing except for those on non-esterified fatty acids, for which only $78 \%$ of the samples were analysed. The alcohol consumption of the study population was known to be high. ${ }^{13}$ The mean corpuscular volume, a parameter correlated with alcohol consumption, ${ }^{14}$ was also included as a possible risk factor for early death.

The men were followed up for survival and causes of death for 12.6 to 18.3 years (average 15.6 years). Inquiries were made through official sources to ascertain the date of death of deceased subjects. The International Classification of Diseases ${ }^{15}$ was used to code the causes of death, which were based on information from the treating physician, hospital records, and the subject's family. Although the survival follow up was complete, the cause of death was established in only $72 \%$ of subjects who had died.

The Cox proportional hazards model was used to describe the survival of men with impaired glucose tolerance or diabetes after adjustment for age, in comparison with the normoglycaemic men. ${ }^{16}$ The resulting hazards ratios have been referred to as relative risks. Survival curves were estimated from this model at age 50. As the effects of risk factors were not always linear, subjects were divided into two classes according to the upper quartile of the risk factor distributions at the first follow up examination. The Cox models were used to assess the effect of each risk factor after adjustment for age. The initial models included interaction terms between the impaired glucose tolerance and diabetic groups and the risk factor concerned, and the homogeneity of the effect of

TABLE I-Characteristics of men in the Paris prospective study according to glucose tolerance. Values are medians (quartiles) unless stated otherwise

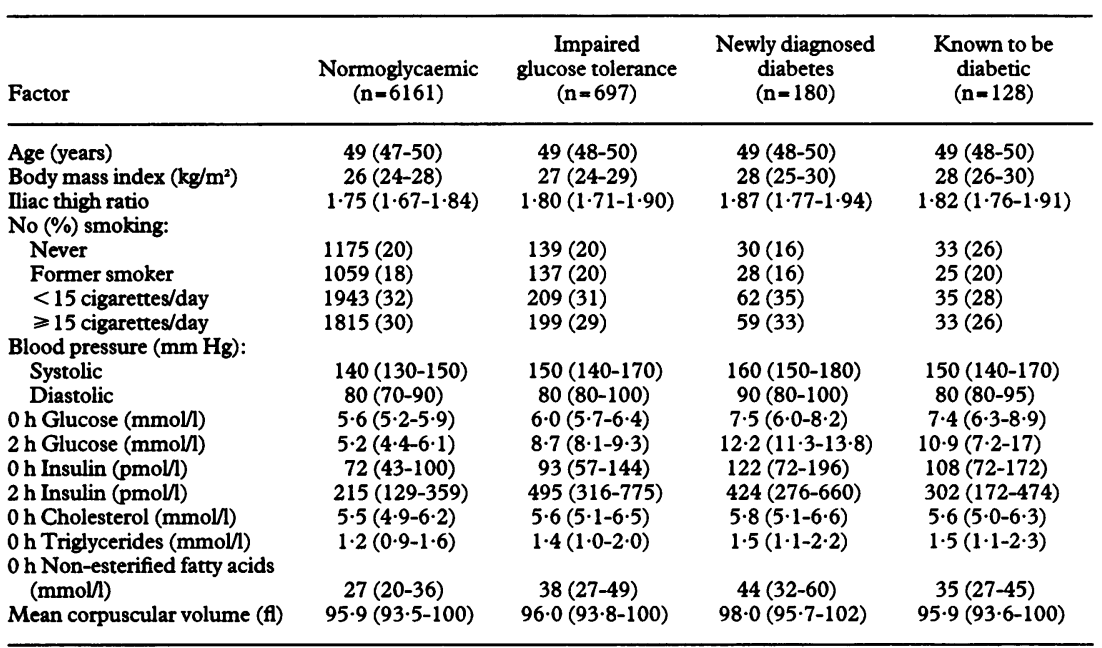

this risk factor was tested in men with impaired glucose tolerance or diabetes by comparing the log-likelihoods of models with and without interaction terms. The relative risks of death were estimated from the resulting model.

A further comparison of likelihoods was made to see whether the trend across the four risk factor classes defined by the quartiles differed significantly from linearity. In order to test whether glycaemic control was beneficial for those subjects known to be diabetic, the fasting and the two hour glucose concentrations were each divided into two classes (fasting $<7.8$ and $\geqslant 7.8 \mathrm{mmol} /$; two hour $<11.1$ and $\geqslant 11.1 \mathrm{mmol} / \mathrm{l})$. A forward algorithm was used to select the prognostic factors, which were all dichotomised above or below the upper quartile or in the case of smoking at 15 or more cigarettes per day. Interaction terms found to be significant in the univariate analysis were always included with the risk factor. To bonfirm this selection of predictive factors a forward model was also used with variables expressed in continuous form. BDMP software was used for all analyses.

\section{Results}

The median levels of most risk factors increased with decreasing glucose tolerance, as defined by the oral glucose tolerance test (table I). For smoking habits and the two hour insulin concentration, however, the levels were higher in men who had impaired glucose tolerance than in those who had had diabetes newly diagnosed. The median levels of all factors were lower for the men already known to be diabetic than for those who had been newly diagnosed.

There were 975 deaths in this cohort, and table II shows the causes of death. In all $349(42 \%)$ of the deaths were due to cancers of various types, $167(20 \%)$ to diseases of the circulatory system, and $142(17 \%)$ to poorly defined causes. No cause could be assigned to 139 of the deaths. Deceased men for whom the cause of death was not known, did not differ significantly from men with known cause of death for any of the characteristics studied. The relative risks of death by any cause followed the same pattern as the risk factors in table I-an increasing trend with increasing glucose intolerance with new diabetic men having a slightly higher risk than known diabetic men. The survival curves for the four groups (figure) show the same trend, with the survival probability of new and known diabetic men diverging after 10 years' follow up.

Both groups of diabetic men had similar relative risks for neoplasms and diseases of the circulatory system. The impaired glucose tolerant and the newly diagnosed diabetic men had very high risks of diseases of the digestive system as noted previously. ${ }^{213}$ Sudden death was listed as the cause of death for 106 of the 142 subjects classified in the group symptoms, signs, and ill defined conditions. For these 106 subjects the associated relative risks were 1.6 (95\% confidence interval 0.90 to

TABLE II-Causes of death after average of 15.6 years of follow up and relative risk ( $95 \%$ confidence interval) of death

\begin{tabular}{|c|c|c|c|c|c|}
\hline & $\begin{array}{l}\text { No (\%) of } \\
\text { subjects }{ }^{\star}\end{array}$ & $\begin{array}{c}\text { Normoglycaemic } \\
(n=6161)\end{array}$ & $\begin{array}{l}\text { Impaired } \\
\text { glucose tolerance } \\
(\mathrm{n}=697)\end{array}$ & $\begin{array}{l}\text { Newly diagnosed } \\
\text { diabetes } \\
(n=180)\end{array}$ & $\begin{array}{l}\text { Known to be } \\
\text { diabetic } \\
(n=128)\end{array}$ \\
\hline $\begin{array}{l}\text { No }(\%) \text { died } \\
\text { Cause of death: }\end{array}$ & & 757 (12) & $132(19)$ & $56(31)$ & $30(23)$ \\
\hline $\begin{array}{l}\text { Neoplasm } \\
\text { Disease of the circulatory system } \\
\text { Disease of the digestive system } \\
\text { Symptoms, signs, and ill defined conditions } \\
\text { Injury and poisoning } \\
\text { All other causes } \\
\text { Unknown causes }\end{array}$ & $\begin{array}{l}349(42) \\
167(20) \\
55(7) \\
142(17) \\
82(10) \\
41(5) \\
139\end{array}$ & $\begin{array}{l}1 \\
1 \\
1 \\
1 \\
1 \\
1 \\
1\end{array}$ & $\begin{array}{l}1.4(1.0 \text { to } 2.0) \\
1.6(1.0 \text { to } 2.6) \\
4.6(2.4 \text { to } 8.5) \\
1.7(1.0 \text { to } 8.9) \\
1.0(0.50 \text { to } 2.2) \\
0.9(0.27 \text { to } 3.0) \\
1.6(0.99 \text { to } 2.7)\end{array}$ & $\begin{array}{l}2.0(1 \cdot 1 \text { to } 3 \cdot 3) \\
2 \cdot 2(1 \cdot 1 \text { to } 4 \cdot 6) \\
11(5 \cdot 0 \text { to } 23) \\
3 \cdot 0(1.5 \text { to } 6 \cdot 0) \\
1.0(0.25 \text { to } 4 \cdot 3) \\
4 \cdot 5(1.6 \text { to } 13) \\
3.0(0.70 \text { to } 5 \cdot 6)\end{array}$ & $\begin{array}{l}2.0(1.1 \text { to } 3.7) \\
2.3(1.0 \text { to } 5 \cdot 3) \\
1.7(0.23 \text { to } 13) \\
1.9(0.69 \text { to } 5 \cdot 1) \\
1.4(0.35 \text { to } 6.0) \\
4.7(1.4 \text { to } 16) \\
1.4(0.45 \text { to } 4.5)\end{array}$ \\
\hline All causes & 975 & 1 & $1.6(1.3$ to 2.0$)$ & $2.7(2.0$ to 3.6$)$ & $2.0(1.4$ to 3.0$)$ \\
\hline
\end{tabular}

*Percentage of subjects with death of known cause classified by International Classification of Diseases. ${ }^{15}$ 
TABLE III-Relative risks of factors predictive of death by all causes estimated from the Cox model after adjustment for age. If the effect differed significantly across glucose tolerance or diabetes classes it is shown according to such classes

\begin{tabular}{|c|c|c|}
\hline Factors & p Value & $\begin{array}{c}\text { Relative risk } \\
\text { (95\% confidence interval) }\end{array}$ \\
\hline $\begin{array}{l}\text { Body mass index } \geqslant 28 v<28 \mathrm{~kg} / \mathrm{m}^{2} \\
\text { lliac thigh ratio } \geqslant 1.85 v<1 \cdot 85^{\star} \text { : }\end{array}$ & 0.02 & $1.2(1.03$ to 1.4$)$ \\
\hline $\begin{array}{l}\text { Not known to be diabetic } \\
\text { Known to be diabetic }\end{array}$ & $\begin{array}{l}0.0001 \\
0.07\end{array}$ & $\begin{array}{l}1.6(1.4 \text { to } 1.9) \\
1.9(0.94 \text { to } 4.0)\end{array}$ \\
\hline \multicolumn{3}{|l|}{ Smoking: } \\
\hline$\geqslant 15$ cigarettes/day $v<15$ cigarettes/day & 0.0001 & $2 \cdot 1(1.8$ to $2 \cdot 4)$ \\
\hline Current smoker $<15$ cigarettes/day $v$ non-smoker & 0.0001 & $1.5(1.2$ to 1.8$)$ \\
\hline Former smoker $v$ never smoked & 1 & $1.0(0.77$ to 1.3$)$ \\
\hline Systolic blood pressure $\geqslant 150 v<150 \mathrm{~mm} \mathrm{Hg}$ & 0.0001 & $1.9(1.6$ to 2.2$)$ \\
\hline Diastolic blood pressure $\geqslant 90 v<90 \mathrm{~mm} \mathrm{Hg}^{\star}$ & 0.0001 & $1.6(1.4$ to 1.9$)$ \\
\hline \multirow{2}{*}{\multicolumn{3}{|c|}{$\begin{array}{l}0 \mathrm{~h} \text { Glucose } \geqslant 7.8 v<7.8 \mathrm{mmol} / \mathrm{:} \\
\text { Known to be diabetic }\end{array}$}} \\
\hline & 0.4 & $1.4(0.64$ to 3.0$)$ \\
\hline $\begin{array}{l}2 \mathrm{~h} \text { Glucose } \geqslant 11 \cdot 1 v<11 \cdot 1 \mathrm{mmol} / \mathrm{:} \\
\text { Known to be diabetic } \\
0 \mathrm{~h} \text { Insulin } \geqslant 108 v<108 \mathrm{pmol} / \mathrm{:}\end{array}$ & 0.003 & $3.8(1.4$ to 9.4$)$ \\
\hline \multicolumn{3}{|l|}{$0 \mathrm{~h}$ Insulin $\geqslant 108 v<108 \mathrm{pmol} / \mathrm{:}$} \\
\hline Known to be diabetic & 0.03 & $2.5(1.1$ to $5 \cdot 8)$ \\
\hline \multicolumn{3}{|l|}{$2 \mathrm{~h}$ Insulin $\geqslant 409 v<409 \mathrm{pmol} / \mathrm{l}$ : } \\
\hline $\begin{array}{l}\text { Not known to be diabetic } \\
\text { Known to be diabetic }\end{array}$ & $\begin{array}{l}0.02 \\
0.04\end{array}$ & $\begin{array}{l}1.2(1.00 \text { to } 1.4) \\
2.4(1.09 \text { to } 5.4)\end{array}$ \\
\hline $0 \mathrm{~h}$ Cholesterol $\geqslant 6.3 v<6.3 \mathrm{mmol} / h^{\star}$ & 0.5 & $1.05(0.91$ to 1.3$)$ \\
\hline $0 \mathrm{~h}$ Triglycerides $\geqslant 1.7 v<1.7 \mathrm{mmol} / /^{\star}$ & $0 \cdot 2$ & $1.1(0.95$ to 1.3$)$ \\
\hline $\begin{array}{l}0 \mathrm{~h} \text { Non-esterified fatty acids } \geqslant 38 v<38 \mathrm{mmol} / / \\
\text { Mean corpuscular volume } \geqslant 100 v<100 \mathrm{fl}^{\star} \text { : }\end{array}$ & 0.0001 & $2 \cdot 0(1 \cdot 7$ to $2 \cdot 3)$ \\
\hline $\begin{array}{l}\text { Not known to be diabetic } \\
\text { Known to be diabetic }\end{array}$ & $\begin{array}{l}0.0001 \\
0.002\end{array}$ & $\begin{array}{l}1.9(1.6 \text { to } 2.2) \\
3.3(1.6 \text { to } 7.0)\end{array}$ \\
\hline
\end{tabular}

*Trend across groups defined by quartiles not significantly different from linear.

TABLE IV-Multivariate Cox model analysis of the factors predictive of death by all causes. Factors were selected by a forward algorithm ( $p$ value for entry to model shown) after adjustment for age

\begin{tabular}{|c|c|c|c|c|}
\hline \multirow[b]{2}{*}{ Factors } & \multicolumn{2}{|c|}{$\begin{array}{l}\text { Without non-esterified } \\
\text { fatty acids }\end{array}$} & \multicolumn{2}{|c|}{$\begin{array}{l}\text { With non-esterified } \\
\text { fatty acids }\end{array}$} \\
\hline & $\mathrm{p}$ Value & $\begin{array}{l}\text { Relative risk } \\
\text { ( } 95 \% \text { confidence } \\
\text { interval) }\end{array}$ & $\mathrm{p}$ Value & $\begin{array}{l}\text { Relative risk } \\
\text { (95\% confidence } \\
\text { interval) }\end{array}$ \\
\hline Smoking ( $\geqslant 15$ cigarettes/day) & 0.0001 & $2 \cdot 0(1 \cdot 7$ to $2 \cdot 3)$ & 0.0001 & $2.0(1.7$ to 2.3$)$ \\
\hline Systolic blood pressure ( $\geqslant 150 \mathrm{~mm} \mathrm{Hg}$ ) & 0.0001 & $1.9(1.6$ to 2.2$)$ & 0.0001 & $1.8(1.5$ to 2.1$)$ \\
\hline Non-esterified fatty acids $(\geqslant 38 \mathrm{mmol} /$ & & & 0.0001 & $1.6(1.3$ to 1.9$)$ \\
\hline Mean corpuscular volume $(\geqslant 100 \mathrm{f})$ & 0.0001 & & 0.0001 & \\
\hline $\begin{array}{l}\text { Not known to be diabetic } \\
\text { Known to be diabetic }\end{array}$ & & $\begin{array}{l}1.6(1.4 \text { to } 1.9) \\
3.1(1.3 \text { to } 7.1)\end{array}$ & & $\begin{array}{l}1.5(1.2 \text { to } 1.8) \\
2.5(1.6 \text { to } 4.0)\end{array}$ \\
\hline Iliac thigh ratio $(\geqslant 1.85)$ & 0.0001 & & 0.001 & \\
\hline $\begin{array}{l}\text { Not known to be diabetic } \\
\text { Known to be diabetic }\end{array}$ & & $\begin{array}{l}1.4(1.2 \text { to } 1.6) \\
2.2(0.95 \text { to } 4.9)\end{array}$ & & $\begin{array}{l}1.3(1.1 \text { to } 1.6) \\
1.6(0.96 \text { to } 2.6)\end{array}$ \\
\hline $2 \mathrm{~h}$ Insulin $(\geqslant 409 \mathrm{pmol} / \mathrm{h})$ & 0.005 & & 0.005 & \\
\hline $\begin{array}{l}\text { Not known to be diabetic } \\
\text { Known to be diabetic } \\
\text { After adjustment for the above factors: }\end{array}$ & & $\begin{array}{l}1.04(0.89 \text { to } 1.2) \\
4.0(2 \cdot 6 \text { to } 6 \cdot 1)\end{array}$ & & $\begin{array}{l}0.98(0.83 \text { to } 1.2) \\
4.3(2.8 \text { to } 6.7)\end{array}$ \\
\hline $\begin{array}{l}\text { Impaired glucose tolerance } v \text { normoglycaemic } \\
\text { Newly diagnosed diabetes } v \text { normoglycaemic } \\
\text { Known to be diabetic } v \text { normoglycaemic }\end{array}$ & & $\begin{array}{l}1.4(1.1 \text { to } 1.8) \\
1.8(1.3 \text { to } 2.5) \\
1.05(0.58 \text { to } 1.9)\end{array}$ & & $\begin{array}{r}1.2(0.94 \text { to } 1.5) \\
1.5(1.08 \text { to } 2.1) \\
0.88(0.45 \text { to } 1.7)\end{array}$ \\
\hline
\end{tabular}

$2.8), 3.7(1.7$ to 7.6$)$, and $2.0(0.61$ to 6.2$)$ in the impaired glucose tolerant, new diabetic, and the known diabetic men respectively. In France, sudden death is often considered to be coronary heart disease. ${ }^{17}$

Table III shows the results of the univariate analysis of the risk factors associated with early death after adjustment for age. Several factors had a significant effect on early mortality independent of the subject's glucose tolerance status or whether he was known to be diabetic. These were body mass index $\left(\geqslant 28 \mathrm{~kg} / \mathrm{m}^{2}\right)$, current smoker, high systolic and diastolic blood pressures $(\geqslant 150$ and $\geqslant 90 \mathrm{~mm} \mathrm{Hg}$ ), and high fasting non-esterified fatty acid concentration ( $\geqslant 38 \mathrm{mmol} / \mathrm{l}$ ). High fasting and two hour insulin concentrations $(\geqslant 108$ and $\geqslant 409 \mathrm{pmol} / /$ respectively) were predictive of death in all men, but the relative risk was significantly different and roughly doubled in men known to be diabetic compared with men not known to be diabetic. Similarly, a high mean corpuscular volume $(\geqslant 100 \mathrm{fl})$ was associated with a greater relative risk in men known to be diabetic. Central obesity, as measured by the iliac thigh ratio had a significant effect only in those men not known to be diabetic. All risk factors had the same effect across the three glucose tolerance groups. Post glucose load values were available in only 105 $(82 \%)$ of the known diabetic men, but there were no differences in the characteristics of those with and without post load values. For the known diabetic men, poor glycaemic control (two hour glucose $\geqslant 11 \cdot 1$ $\mathrm{mmol} / \mathrm{l}$ ) was predictive of early death, with a relative risk of almost 4.0 compared with known diabetic men with good control. The fasting glucose concentration did not have a significant effect.

Nine risk factors were found to be associated with mortality in subjects known to be diabetic and not known to be diabetic. The average number of raised values for risk factors (above the upper quartile) was 2.5 in normoglycaemic men, 4.1 in men with impaired glucose tolerance, $5 \cdot 1$ in newly diagnosed diabetic men, and 4.0 in men known to be diabetic.

The variables selected for a multivariate model with a forward algorithm, are shown in table IV. As there were missing data on non-esterified fatty acid concentration, the table shows the results with and without this factor. Heavy cigarette smoking and high systolic blood pressure were most predictive of early death. After adjustment for these two variables mean corpuscular volume, the iliac thigh ratio, and the two hour insulin concentrations were significant. The risk was significantly higher in subjects known to be diabetic for mean corpuscular volume and two hour insulin concentration. When non-esterified fatty acids were included in the model, their concentration was significant after adjustment for smoking and systolic blood pressure. The results changed little with this added factor. These results remained the same when the risk factors were analysed as continuous variables.

After adjustment for the risk factors in the multivariate models, men with impaired glucose tolerance and newly diagnosed diabetes had significantly higher relative risks of death compared with normoglycaemic men $(p<0.05)$. The risk in known diabetic men was similar to that in normoglycaemic men (table IV). After adjustment for the non-esterified fatty acid concentration, only men with newly diagnosed diabetes had a higher relative risk of death than men with normal glucose tolerance.

\section{Discussion}

OTHER STUDIES

Several prospective studies have examined the risk factors associated with early death in non-insulin dependent diabetic subjects: six cohort studies of diabetic subjects, ${ }^{18-23}$ seven studies of cohorts that have included diabetic subjects (including the current study), ${ }^{324-28}$ and one case-control study ${ }^{29}$ These studies must be compared with caution: since some give combined results for men and women ${ }^{18192122279}$ and only the Whitehall, ${ }^{25}{ }^{26}$ Rancho-Bernardo, ${ }^{24}$ and the Paris prospective studies included an oral glucose tolerance test to screen for new diabetic subjects. Fasting glucose concentration was used to diagnose diabetes in the Dallas study. ${ }^{28}$ In addition, some cohorts included patients treated with insulin, ${ }^{3232427} 29$ who could have had insulin dependent diabetes whereas others did not indicate whether the diabetic subjects were treated with insulin ${ }^{1921}$ or whether insulin dependent subjects were included.

One study excluded subjects with a history of myocardial infarction ${ }^{3}$ and in another subjects were selected only if they were free of clinical vascular disease and were able to achieve a predetermined heart rate after exercise. ${ }^{28}$ The Rancho-Bernardo study identified risk factors in the combined population of diabetic and non-diabetic subjects without any test for homogeneity of effect between these groups. ${ }^{24}$ The reference group used in studies also differed. Some studies used subjects not known to be diabetic, ${ }^{327}$ others used subjects not known to be diabetic or newly diagnosed as diabetic, ${ }^{24} 26$ and others used normoglycaemic subjects. ${ }^{2528} 29$ 
RELATIVE RISK OF EARLY MORTALITY IN DIABETIC SUBJECTS

In the studies which included a comparison group ${ }^{34-29}$ diabetic subjects had a relative risk of death of between 1.5 and 3.5 , with no clear relation being evident between the length of follow up, the age of the subjects, or their sex. Jarrett and Shipley were the only authors who analysed the newly diagnosed diabetic subjects separately. ${ }^{25}$ These subjects had a relative risk of death of 2.6 ( $95 \%$ confidence interval 1.8 to $3 \cdot 7$ ), higher than that of the known diabetic subjects, which ranged from 1.7 to 2.2 depending on the duration of diabetes, and similar to the relative risk of 2.0 in our study. The impaired glucose tolerant group had similar risks in both studies.

RISK FACTORS FOR EARLY MORTALITY IN DIABETIC SUBJECTS

In 1990 Jarrett commented on the lack of consistency between studies of risk factors for mortality from all causes in diabetic subjects. ${ }^{30}$ Overall obesity was studied in all but one of the cohorts. In most cases it had no effect but in the Japanese cohort deceased subjects were less obese. ${ }^{19}$ In contrast, in our study obesity was associated with an increased risk $(\mathrm{p}<0.02)$ but abdominal obesity was more important than overall obesity $(p<0.0001)$. The distribution of body fat has not been analysed previously. The relation between central adiposity, non-esterified fatty acid concentration, and the risk factors analysed here suggests that raised non-esterified fatty acid concentration may have a role in early mortality. ${ }^{31}$

Smoking and high blood pressure or hypertension have been found to be risk factors in most studies. In contrast, dyslipidaemia has rarely been found to be important. Glycaemic control in subjects known to be diabetic has been found significant in most studies.

The Oxford study of 249 diabetic subjects was the only other study to analyse insulin as a risk factor. ${ }^{18}$ Insulin concentrations, both fasting and after intravenous glucose were higher in those who died. We found that a high fasting insulin concentration carried a relative risk of $2.5(2.4$ for two hour insulin) in men known to be diabetic.

Even though alcohol is well recognised as a risk factor for early death, ${ }^{32}$ the Gothenberg study ${ }^{3}$ was the only other cohort study which analysed the effect of excessive alcohol consumption. After adjustment for several other factors, registered alcohol misuse in that study was a significant risk factor for all cause mortality in non-diabetic men, with a relative risk of $2 \cdot 6$. Alcohol misuse, however, was not significant in diabetic men (relative risk 0.8 ) even though there were significantly more alcohol misusers in the diabetic group. As the diabetic population was small the significance of alcohol misuse may have been lost by adjusting for other factors. We found that a high mean corpuscular volume, a marker for excessive alcohol consumption, was predictive of early death, with a relative risk of 1.9 in subjects not known to be diabetic and 3.3 in subjects known to be diabetic.

COMPARISON OF RISK FACTORS IN DIABETIC AND NONDIABETIC SUBJECTS

In this study and the other cohorts with a reference group $^{324-29}$ the risk factors for death in diabetic and non-diabetic subjects were generally the same. When risk factors differed the factor was often significant in the control group but not in the diabetic group-for example systolic blood pressure in the Gothenburg study, ${ }^{3}$ and the cholesterol concentration and systolic blood pressure in the Whitehall study. ${ }^{26}$ This could be due to the small sample of diabetic subjects and the fact that the range of values was too narrow to pick up significant effects. The analysis is more powerful if all

\section{Clinical implications}

- Age specific mortality in non-insulin diabetic patients is twice that in the general population

- The excess mortality has been mainly attributed to ischaemic heart disease

- In this study most of the risk factors for early mortality in diabetic men were the same as in non-diabetic men-obesity, smoking, and high blood pressure

- Poor glycaemic control and a high mean corpuscular volume were also risk factors in diabetic men

- The importance of a healthy lifestyle and good control of diabetes should be emphasised to diabetic patients

the data are used and interactions tested. Two factors have been reported that were not significant in nondiabetic subjects but significant in the diabetic groups: systolic blood pressure in the Dallas study ${ }^{28}$ and triglyceride concentration in the Danish study. ${ }^{29}$ In our study the effect of hyperinsulinaemia in subjects known and not known to be diabetic differed significantly, with a twofold increase in risk of death for those known to be diabetic compared with the rest of the cohort.

We found glucose intolerance to be a significant risk factor in men not known to be diabetic even after adjustment for other risk factors. This agrees with the results in the Whitehall study ${ }^{25}$ and the fit men of the Dallas study.$^{28}$ Subjects known to be diabetic who were still hyperinsulinaemic (either at fasting or at two hours after the glucose load) had an increased risk of death compared with those whose insulin concentrations were lower: among subjects known to be diabetic $48 \%$ had raised fasting concentrations and $12 \%$ raised two hour concentrations, compared with $25 \%$ of those who were not diabetic.

\section{CONCLUSIONS}

In summary, the factors consistently identified as risk factors for early death in non-insulin dependent diabetic subjects are high blood pressure and cigarette smoking. Further investigation is needed to confirm the effects of glucose control, insulin concentrations, central obesity, non-esterified fatty acids, and excessive alcohol consumption.

The advice for diabetic subjects about reducing risk of early death is generally similar to that for nondiabetic subjects. They should stop smoking, and reduce both overall and central obesity and excessive alcohol consumption. Increased physical activity may be a key factor since it would reduce obesity, hypertension, and insulin resistance. When considering pharmacological treatment of any risk factor doctors must take into account the drug's effect on other risk factors, in particular glycaemic control, especially in diabetic subjects.

The Paris prospective study is conducted by Groupe d'Etudes sur l'Epidémiologie de l'Athérosclerose and is supported by Institut National de la Santé et de la Recherche Medical (Units 21, 55, 169, and 258) and the Direction de l'Action Sociale, de l'Enfance et de la Santé de la Ville de Paris.

1 Panzram G. Mortality and survival in type 2 (non-insulin-dependent) diabetes mellitus. Diabetologia 1987;30:123-31.

2 Balkau B, Eschwège E, Ducimetière $P$, Richard J-1, Warnet J-M. The high risk of death by alcohol related diseases in subjects diagnosed as diabetic and risk of death by alcohol related diseases in subjects diagnosed as diabetic and follow-up. I Clin Epidemiol 1991;44:465-74.

3 Rosengren A, Welin L, Tsipogianni A, Wilhelmsen L. Impact of cardio- 
vascular risk factors on coronary heart disease and mortality among middle aged diabetic men: a general population study. $B M \mp$ 1989;299:1127-31.

4 Ducimetière $\mathrm{P}$, Richard J-L, Claude J-R, Warnet J-M. Les cardiopathies ischemiques, incidence et facteurs de risque. L'erude prospective Parisienne. Paris: Editions INSERM, 1981:9-20.

5 Ducimetière $\mathrm{P}$, Eschwège E, Papoz L, Richard J-L, Claude J-R, Rosselin GE. Relationship of plasma insulin levels to the incidence of myocardial infarction and coronary heart disease mortality in a middle-aged population. Diabetologia 1980;19:205-10.

6 World Health Organisation Study Group. Diabetes mellitus. WHO Tech Rep Series 1985 ; No 727.

7 Ducimetière P, Richard J-L. The relationship between subsets of anthropometric upper versus lower body measurements and coronary heart disease risk in middle-aged men. The Paris prospective study I. Int $f$ Obesit 1989;13:111-22

8 Etienne G, Papin JP, Renault M. Une méthode simple de dosage du cholestérol par voie automatique. Ann Biol Clin 1963;21:851-9.

9 Claude JR, Corre F. Considérations pratiques sur le dosage semi-automatique des triglycérides sériques par fluoromérrie (méthode de Kiessler et Lederer) Comparison avec la méthode manuelle colorimétrique de Van Handel et Zilversmit. Ann Biol Clin 1968;26:451-4.

10 Méthodologie Technicon auto-analyser " $N$ " 2a, 2nd Ed. London: Technicon, 1963.

11 Antonis A Semi-automated method for the colorimetric determination of plasma free fatty acid. 9 Lipid Res 1965:6:307-12.

12 Rosselin GE, Assan R, Yalow RS, Berson SA. Separation of antibody bound and unbound peptide hormone labelled with iodine 131 by talcum powder and precipitated silica. Nature 1966;212:355-7.

13 Balkau B, Eschwège E, Fontbonne A, Claude J-R, Warnet J-M. Cardiovascular and alcohol-related deaths in abnormal glucose tolerant and diabetic subjects. Diabetologia 1992;35:39-44.

14 Papoz L, Warnet J-M, Pequignot G, Eschwège E, Claude J-R, Schwartz D. Alcohol consumption in a healthy population. Relationship to $\gamma$-glutamy transferase activity and mean corpuscular volume. FAMA 1981;245: 1748-51.

15 International Classification of Diseases. Manual for the international classification of diseases, injuries and causes of death. 8th revision. Geneva: WHO, 1968.

16 Cox DR. Regression models and life-tables (with discussion). foumal of the Royal Statist Society 1971;34B:187-220.

17 Eschwège E, Richard J-L, Thibult N, Ducimitière $\mathrm{P}$, Warnet J-M, Claude J-R, Rosselin GE. Coronary heart disease mortality in relation with diabetes, blood glucose and plasma insulin levels. The Paris prospective study; ten years later. Hormone Metab 1985;15:41-6.
18 Coppack SW, Doll HA, Pim B, Hockaday TDR. Intravenous glucose tolerance and mortality in non-insulin-dependent diabetes mellitus. Qf Med 1990;75:451-60.

19 Sasaki A, Horiuchi N, Hasegawa K, Uehara M. Mortality and causes of death in type 2 diabetic patients. A long-term follow-up study in Osaka district, Japan. Diabetes Res Clin Pract 1989;7:33-40.

20 Morrish NJ, Stevens LK, Head J, Fuller JH, Jarrett RJ, Keen H. A prospective study of mortality among middle-aged diabetic patients (the London cohort of the WHO multinational study of vascular disease in diabetics) II: associated risk factors. Diabetologia 1990;33:542-8.

21 Tountas C, Kofinis A, Kardoyiannis T, Pavlopoulos B, Karamanos B. Factors associated with the 10-year survival of a cohort of diaberic patients. Diabetologia 1987;330:589A.

22 Schmitz A, Vaeth M. Microalbuminuria and mortality in non-insulin dependent diabetes. Diabetes Metab 1988;14:193.

23 Knuiman MW, Welbom TA, Whittall DE. An analysis of excess mortality rates for persons with non-insulin-dependent diabetes mellitus in Western Australia using the Cox proportional hazards regression model. Am F Epidemiol 1992;135:638-48.

24 Barrett-Connor E, Wingard DL. Sex differential in ischaemic heart disease mortality in diabetics: a prospective population-based study. $\mathrm{Am}$ f Epidemiol 1983;118:489-96.

25 Jarrett RJ, Shipley MJ. Type 2 (non-insulin-dependent) diabetes mellitus and cardiovascular disease-putative association via common antecedents; further evidence from the Whitehall study. Diabetologia 1988;31:737-40.

26 Fitzgerald AP, Jarrett RJ. Are conventional risk factors for mortality relevant in type 2 diabetes? Diabetic Med 1991:8:475-80.

27 Ford ES, DeStefano F. Risk factors for mortality from all causes and from coronary heart disease among persons with diabetes. Am $₹$ Epidemio 1991;133:1220-30.

$28 \mathrm{Kohl} \mathrm{HW}$, Gordon NF, Villegas JA, Blair SN. Cardiorespiratory fitness, glycemic status, and mortality risk in men. Diabetes Care 1992;15:184-92.

29 Damsgaard EM, Froland A, Jorgensen OD, Mogensen CE. Eight to nine year mortality in known non-insulin dependent diabetics and controls. Kidney In 1992;41:731-5.

30 Jarrett J. Mortality in diabetes. Qf Med 1990;75:413-4.

31 Björntorp P. Obesity and diabetes. In: Alberti KGMM, Krall LP, eds. The diabetes annual: 5. Amsterdam: Elsevier, 1990:373-95.

32 Anderson P. Excess mortality associated with alcohol consumption. $B M F$ 1988;297:824-6.

(Accepted 21 May 1993)

\section{Paternity by a seemingly infertile vasectomised man}

\section{J A Thomson, P J Lincoln, Phyllis Mortimer}

\section{Department of \\ Haematology, London Hospital Medical College, London E1 2AD \\ J A Thomson, research assistant \\ P J Lincoln, reader in \\ haemogenetics}

Family Planning Service, Croydon Community Health, Croydon, Surrey Phyllis Mortimer, senior clinical medical officer

Correspondence to: Dr Lincoln.

BMF 1993;307:299-300
Vasectomy is a safe, reliable means of sterilisation, easily monitored by examination of semen at suitable intervals after operation. Failed operations, indicated by the presence of spermatozoa in the semen, are usually identified within a few months, although occasionally spermatozoa may reappear much later.

In later failures there can be either high levels of active spermatozoa (due to recanalisation of the vas deferens) or "non-significant" numbers of non-motile spermatozoa. Non-motile spermatozoa have been reported as having no clinical significance, ${ }^{1}$ and no confirmed associated pregnancies have been reported..$^{1-4}$

We report such a pregnancy. It was important from a clinical perspective, and for the benefit of the parties involved, that the true paternity of the child be confirmed.

\section{Case history}

The patient had a vasectomy in December 1987. Semen samples at 12 and 18 weeks after operation were clear of spermatozoa, and he was told that the vasectomy had been successful.

In 1990 his wife became pregnant. Repeated examinations of the husband's semen showed the presence of small numbers of non-motile spermatozoa, a pattern usually thought to indicate infertility. No motile spermatozoa were observed in five specimens.

A child was born in April 1991. It was decided to perform tests, including DNA profiling, to ascertain paternity. Blood samples from the patient, his wife, and the child underwent DNA profiling tests with six single locus DNA probes (Muc 7, MR24/1 (Amersham
International), YNH24, TBQ7, 3' $\alpha$ HVR (Promega), and MS43a (Cellmark Diagnostics)). Nineteen conventional protein polymorphisms were also analysed.

These tests provided no evidence that the patient was not the father of the child. Conventional test results produced a relative chance of paternity of about $94 \%$, and combination with the DNA profiling results, increased the chance of paternity to over $99.999 \%$. Such a figure is considered to offer virtual proof of paternity, provided a close relative of the named man is not a possible father. To eliminate this possibility, the patient's brother was tested and excluded from paternity on two out of five DNA tests utilised.

The wife has now had an intrauterine contraceptive device fitted. There are no immediate plans for a further operation on our patient.

\section{Comment}

This case shows fertilisation by a man deemed infertile by criteria normally accepted as defining successful vasectomy. This single case does not detract from the view that men with very few, non-motile spermatozoa after vasectomy are generally infertile,

Summary of semen examinations and other events

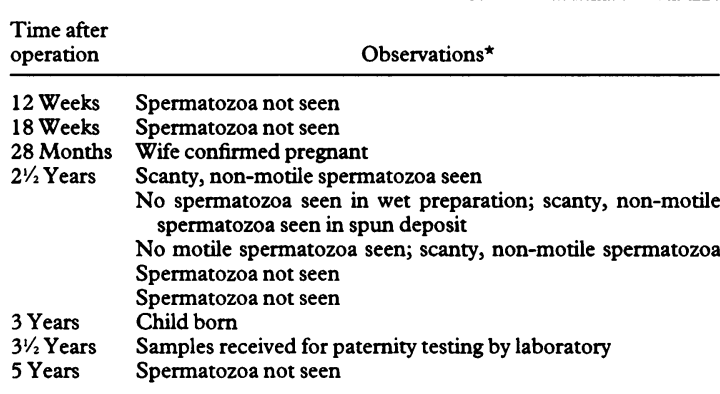

* Semen examinations were carried out on samples a maximum of two hour old and kept at room temperature. The whole film was scanned at $400 \times$ magnification by two members of staff. 